\title{
Effects of Temperature and Salinity on the Survival Rates of Coxicerberus ramosae (Albuquerque, 1978), an Interstitial Isopod of a Sandy Beach on the Coast of Brazil
}

\author{
Elaine Figueiredo Albuquerque ${ }^{1 *}$, Bruno Meurer $^{1}$ and Godofredo da Camara Genofre \\ Netto $^{2}$ \\ ${ }^{1}$ Universidade Santa Úrsula; Rua Fernando Ferrari, 75; 22231-040; Rio de Janeiro - RJ - Brasil. ${ }^{2}$ Universidade de \\ São Paulo; São Paulo - SP - Brasil
}

\begin{abstract}
The tolerance to the combined effects of temperature and salinity was investigated in the interstitial isopod Coxicerberus ramosae (Albuquerque, 1978), a species of intertidal zone of sandy beaches in Rio de Janeiro, Brazil. The animals were collected on Praia Vermelha Beach. The experiments lasted $24 h$ and nine salinities and seven temperatures were used for a total of 63 combinations. Thirty animals were tested in each combination. The species showed high survival in most of the combinations. The temperature of $35{ }^{\circ} \mathrm{C}$ was lethal and at $5{ }^{\circ} \mathrm{C}$, the animals tolerated only a narrow range of salinities. The statistical analyses showed that the effects of temperature and salinity were significant on the survival, which confirmed the euryhalinity and eurythermy of this species.
\end{abstract}

Key words: Interstitial, isopod, resistance, temperature, salinity. Coxicerberus

\section{INTRODUCTION}

Temperature and salinity are considered to be the most important physiological factors influencing marine organisms (Kinne, 1971). The sandy coast between the sea and the continental domain is very unstable with respect to several environmental variables, especially these factors (Coineau, 1985). The distribution of organisms in the interstitial habitat can be better understood through the concomitant study of the effects of specific factors in the laboratory and field. Tolerance and resistance tests can be used to determine the survival capacity of a species in relation to certain factors (Krauss and Found, 1975).
The combined effects of temperature and salinity on the survival of marine animals have been demonstrated in many marine organisms, mainly crustaceans (Todd and Dehnel, 1960; Segal and Burbancki, 1963; Haefner, 1969; Jansen, 1970; Ong and Costlow, 1970; Jones, 1972; Biggs and McDermott, 1973; Sandifer, 1973; Christiansen and Costlow, 1975; Rosenberg and Costlow, 1976; Vlasblom et al., 1977; Young and Hazlett, 1978; Rothlisberg, 1979; Dawirs, 1979; Johnson, 1980; Azis and Greenwood, 1981; Gaudy et al., 1982; Yagi and Ceccaldi, 1983; Roddy et al., 1984; Preston, 1985; Vinuesa et al., 1985; Harms, 1986; Moreira et al.,1982, 1986; Blazskowski and Moreira, 1986; Cadman and Weinstein, 1988;

*Author for correspondence: elaineusu @ hotmail.com 
Avis, 1988; Menet et al., 1991; Young, 1991; Qiu and Qian, 1997, 1998; Lemaire et al., 2002; Paula et al., 2003; Thiyagarajan et al, 2003; Aktas et al., 2004.) The importance of these effects and the need to consider these factors jointly were emphasized by Kinne (1963, 1964 and 1970). Kinne (1970) noted that salinity could modify the effects of temperature and alter the temperature range of many biological processes. In turn, temperature can also modify the effects of salinity. Several experimental studies on interstitial species have been carried out (Gray, 1966 a and b; 1968; Jansson, 1962, 1966, 1967, 1968; Krauss and Found, 1975; Vernberg and Coull, 1975, 1981; Wieser and Schiemer, 1977; Milliou, 1977, 1996; Milliou and Moraitou-Apostolopoulou, 1991). However, similar studies have never been done on interstitial isopods.

Many species of microcerberid isopods live exclusively in the interstitial habitat and most of them inhabit marine and continental waters. The more primitive species probably originated during ocean regressions, dating from the Lower Cretaceous. Many microcrustaceans that presently inhabit continental underground waters had marine ancestors, which initially colonized the interstitial waters of sandy coasts (Boutin and Coineau, 1991).

The genus Coxicerberus includes only marine species, whereas the majority of continental species are members of other microcerberidean genera which have more primitive characters (Wägele, Voelz and McArthur, 1995). In Brazil, five species of Coxicerberus have been described. Coxicerberus ramosae is very abundant on sandy beaches in Rio de Janeiro (Albuquerque, 1978). The aim of this work was to test the resistance of C. ramosae to the combined effects of temperature and salinity.

\section{MATERIAL AND METHODS}

Praia Vermelha Beach, located in Guanabara Bay in the state of Rio de Janeiro, Brazil, at $22^{0} 57$ 'S and $043^{\circ} 9^{\prime} \mathrm{W}$, is part of the Atlantic tropical area. The beach is exposed and its sand is very homogeneous and coarse. The flow of continental underground water is considerable, causing a salinity gradient in the interstitial water. In this beach, the temperature of the interstitial water varies from 20 to $30^{\circ} \mathrm{C}$, and the salinity from 27 to 36 (Albuquerque and Genofre, 1999).

Isopods were collected in the resurgence zone (Salvat, 1964) by the Karaman-Chappuis method (Coineau, 1971). The animals were taken to the laboratory in pots transported in insulated containers. The tolerance of the species under laboratory conditions was studied through two separate tests. In each test, three replicates with 10 animals each were placed in Petri dishes containing filtered sea water at salinity 35 and $22^{\circ} \mathrm{C}$ in a BOD chamber in darkness. A total of 60 animals were tested, 30 per test. During the experiments, the animals were not fed. The dishes were initially examined after six hours, and every $24 \mathrm{~h}$ thereafter. Animals which did not react to the touch of a needle were considered dead, and the experiments ended when the last individual was dead.

To verify the combined effects of temperature and salinity on the species resistance, the experiments included seven temperatures $(5,10,15,20,25,30$ and $\left.35^{\circ} \mathrm{C}\right)$ and nine salinities $(5,10,20,30,35,40$, $50,60,70)$ for a total of 63 combinations. The animals were transferred directly to the experimental conditions according to Dorgelo (1976). Thirty individuals were placed in Petri dishes (10 replicates per group) and they were submitted to temperature and salinity combinations. The experiments finished after $24 \mathrm{~h}$. The animals were not fed during this period. A total of 1890 individuals were tested.

Low-salinity water was obtained by diluting sea water with distilled water. High-salinity water was made by freezing sea water. Salinity was measured with an American Optical/TD salinometer/refractometer. The survival rate was calculated at the end of each experiment.

Two-way analysis of variance (ANOVA) with a 95\% confidence interval $(\mathrm{P}<0.01)$ was used. All data were tested for normality (KolmogorovSmirnov test), and homoscedasticity (Cochran test) to assess the variation in survival of the different temperature and salinity combinations. The Tukey test was used to verify the difference among the treatments (Zar, 1999). The correlation between the survival percentages and the temperature and salinity was estimated by multiple regression analysis. The statistical tests were done using Statistica for Windows v.6.0. 


\section{RESULTS}

Under the laboratory conditions, $50 \%$ of the individuals survived almost 30 days in the first experiment and 24 days in the second (Fig. 1). A survival rate of $100 \%$ for C. ramosae was shown in the first $24 \mathrm{~h}$ on the two experiments, which indicated excellent tolerance under the laboratory conditions.

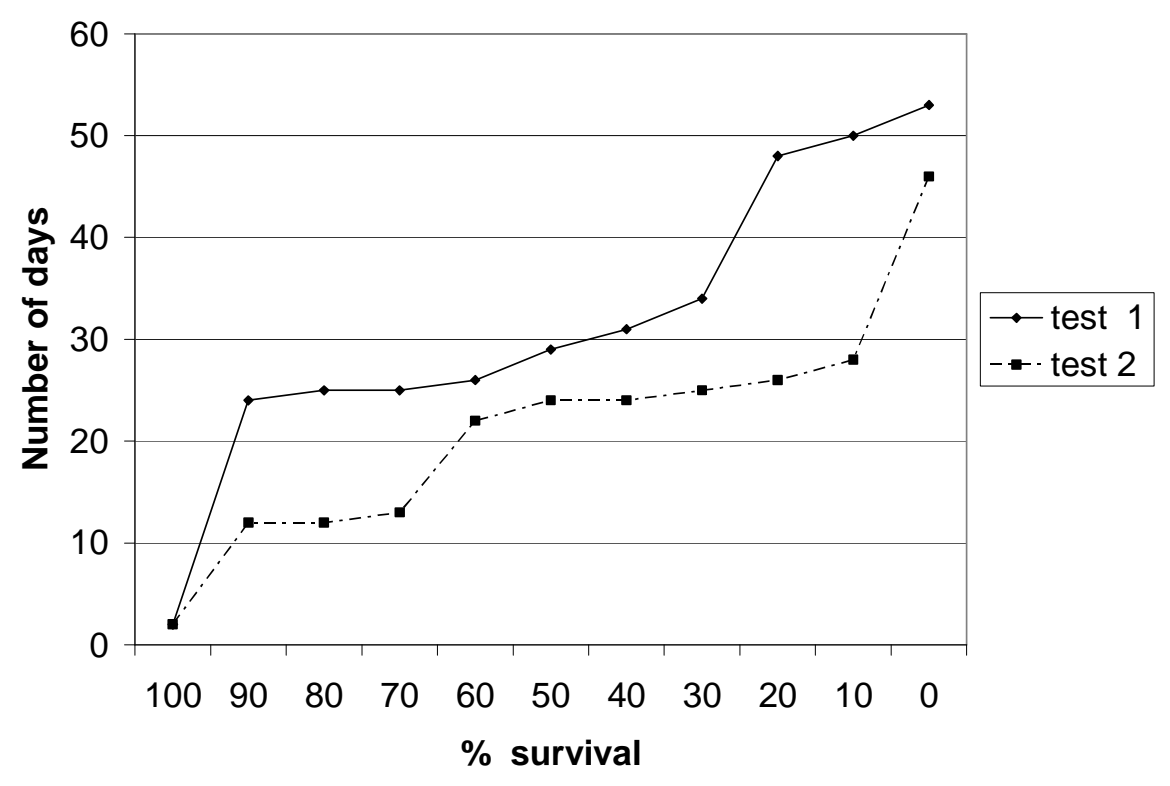

Figure 1 - Tolerance of Coxicerberus ramosae to laboratory conditions.

The results of the experiments using 63 temperature and salinity combinations showed high tolerance of this species to most of the combinations tested (Fig. 2 and 3). Survival rate was high for all the temperatures, except at $35^{\circ} \mathrm{C}$. This temperature was lethal and almost all the individuals died in the salinities tested. At 10, 15 and $30^{\circ} \mathrm{C}$, the survival was more than $50 \%$ in the salinities from 10 to 60 . At $20^{\circ} \mathrm{C}$, the animals only died in the salinity of 5 , and at $25^{\circ} \mathrm{C}$, they died only at salinity of 70 (Fig. 2).

The survival of $C$. ramosae was high at almost all the salinities and more than $50 \%$ survival was observed, except at 5 and 70 . The percentage survival of species was very high at salinity from 30 to 40 in a wide range of temperatures, and the mortality after $24 \mathrm{~h}$ was practically null. All the individuals secreted a mucous layer at low temperatures $\left(5\right.$ and $\left.10^{\circ} \mathrm{C}\right)$ at salinity 5 . At 50 and 60 of salinity, the species presented more than $50 \%$ of survival from 5 to $30^{\circ} \mathrm{C}$. In salinity 70 , $50 \%$ of survival was observed only at $20^{\circ} \mathrm{C}$. After seven hours of experiments, when the animals were submitted to extreme salinities (5 and 70), they became incapable of moving around and only moved their appendages when stimulated by a needle. At 5 of salinity, the species only showed higher resistance at $25^{\circ} \mathrm{C}$ (Fig. 3). 

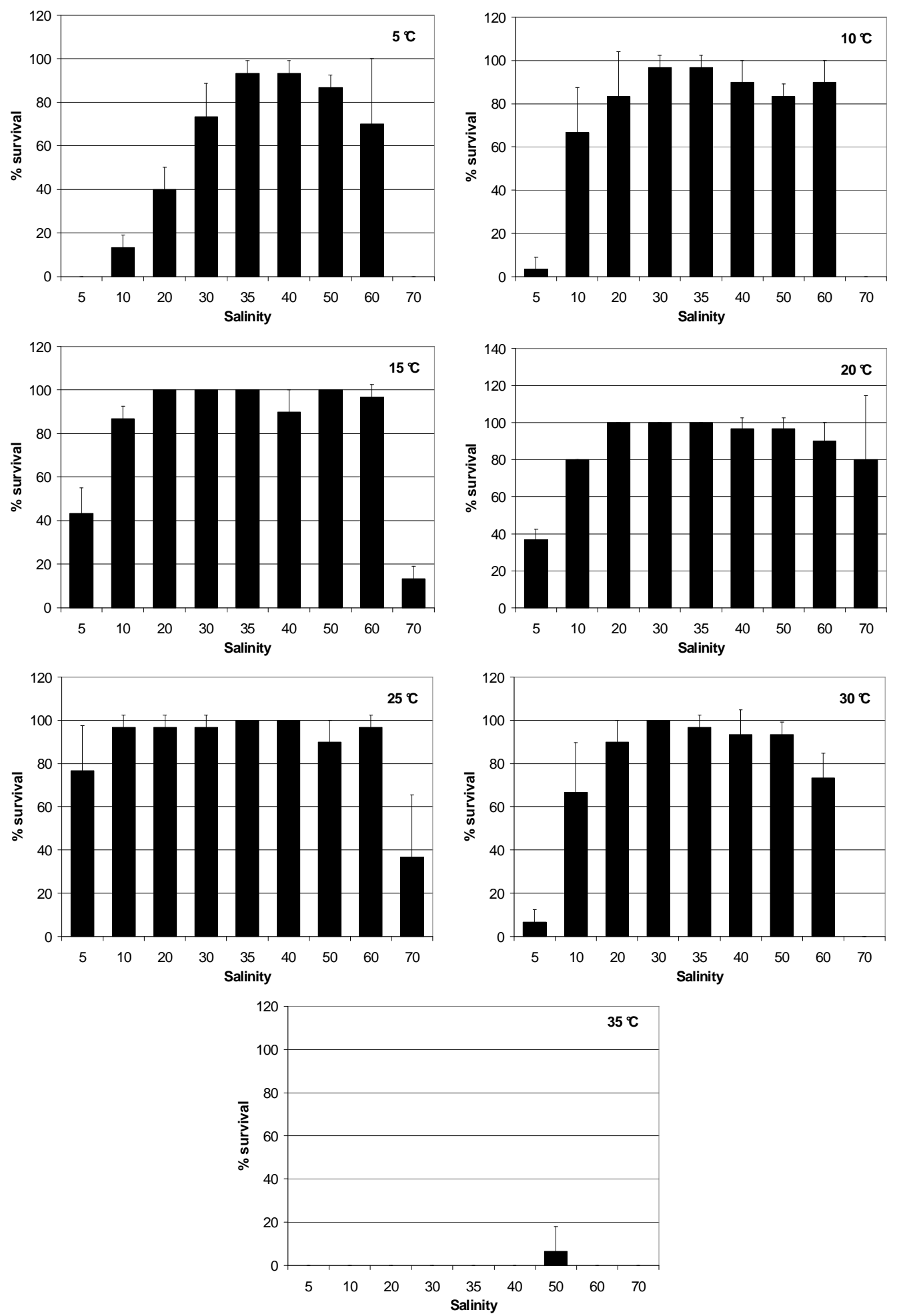

Figure 2 - Mean survival of Coxicerberus ramosae at different temperatures. 

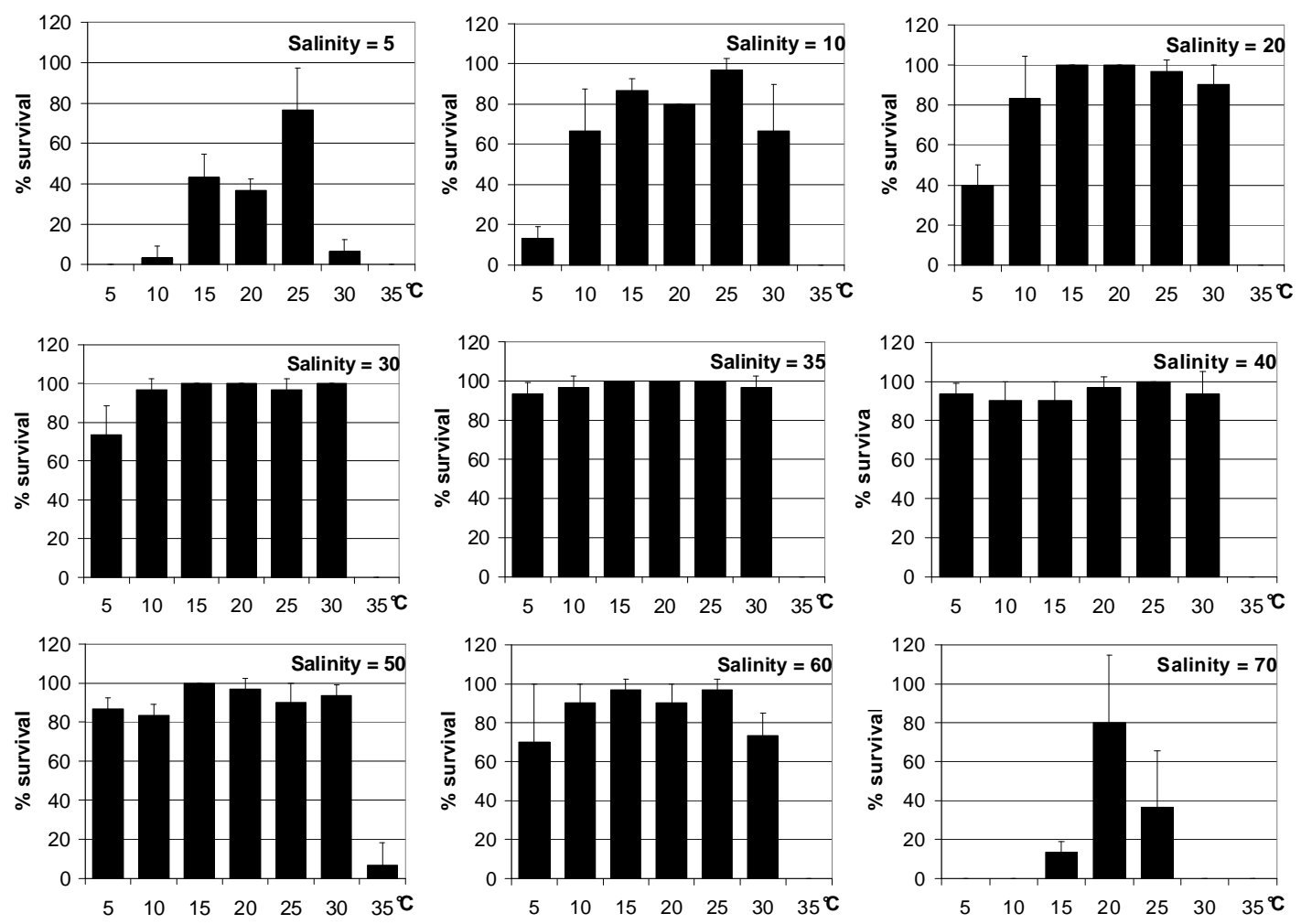

Figure 3 - Mean survival of Coxicerberus ramosae at different salinities.

The analysis of variance of the survival data showed that temperature, salinity and interaction effects were highly significant (Table 1). The Tukey test showed that extreme treatments of temperature $\left(5^{\circ}\right.$ and $\left.35^{\circ} \mathrm{C}\right)$ and salinity $(5,10$ and 70) were responsible for the higher differences (Table 2).

Table 1 - ANOVA comparing the effects of temperature and salinity on Coxicerberus ramosae survival. T= temperature; $\mathrm{S}=$ salinity; $\mathrm{TxS}=$ combined effect of temperature and salinity; $\mathrm{SS}=$ sum of squares; MS= mean squares.

\begin{tabular}{cccccc}
\hline & SS & d.l. & MS & F & p \\
\hline Intercept & 748000.5 & 1 & 748000.5 & 6015.834 & $<0.001$ \\
T & 145818.0 & 6 & 24303.0 & 195.458 & $<0.001$ \\
S & 105689.9 & 8 & 13211.2 & 106.252 & $<0.001$ \\
TxS & 45124.9 & 48 & 940.1 & 7.561 & $<0.001$ \\
Error & 15666.7 & 126 & 124.3 & & \\
\hline
\end{tabular}

Table 2 - Tukey test applied to the different temperature and salinity treatments (95\% confidence interval).S=Salinity; $\mathrm{T}=$ Temperature.

\begin{tabular}{clcl}
\hline S & post- test & $\mathbf{T}^{\mathbf{0}} \mathbf{C}$ & Post-test \\
\hline 5 & $\neq 10 ; 20 ; 30 ; 35 ; 40 ; 50 ; 60$ & 5 & $\neq 10 ; 15 ; 20 ; 25 ; 30 ; 35$ \\
10 & $\neq 5 ; 20 ; 30 ; 35 ; 40 ; 50 ; 60 ; 70$ & 10 & $\neq 5 ; 20 ; 25 ; 35$ \\
20 & $\neq 5 ; 10 ; 35 ; 70$ & 15 & $\neq 5 ; 20 ; 30 ; 35$ \\
30 & $\neq 5 ; 10 ; 70$ & 20 & $\neq 5 ; 10 ; 15 ; 30 ; 35$ \\
35 & $\neq 5 ; 10 ; 20 ; 70$ & 25 & $\neq 5 ; 10 ; 15 ; 30 ; 35$ \\
40 & $\neq 5 ; 10 ; 70$ & 30 & $\neq 5 ; 20 ; 25 ; 35$ \\
50 & $\neq 5 ; 10 ; 70$ & 35 & $\neq 5 ; 10 ; 15 ; 20 ; 25 ; 30$ \\
60 & $\neq 5 ; 10 ; 70$ & & \\
70 & $\neq 10 ; 20 ; 30 ; 35 ; 40 ; 50 ; 60$ & & \\
\hline
\end{tabular}


The different combinations of temperature and salinity showed significant but slight positive correlation $(\mathrm{R} 2=0.06192137)$ with the survival percentage (Table 3). In the partial results of multiple regressions, only temperature was statistically significant $(\mathrm{P}=0.001)$, showing a negative correlation with the percentage survival.

Table 3 - Multiple regression analysis of the combined effects of salinity and temperature on Coxicerberus ramosae (95\% confidence interval). $\mathrm{T}=$ Temperature; $\mathrm{S}=$ Salinity

\begin{tabular}{ccccccc}
\hline & Beta & Std. Err. & B & Std. Err. & t(186) & p-level \\
\hline Intercept & & & 81.09441 & 8.133581 & 9.97032 & 0.000000 \\
T & -0.247307 & 0.071017 & -1.00529 & 0.288681 & -3.48236 & $\mathbf{0 . 0 0 0 6 1 9}$ \\
S & 0.027576 & 0.071017 & 0.05404 & 0.139174 & 0.38830 & 0.698239 \\
\hline
\end{tabular}

$\mathrm{R}^{2}=0.06192137$

$\mathrm{F}(2.186)=6.1388 \mathrm{p}<0.00262$

\section{DISCUSSION}

The results indicated a high resistance of $C$. ramosae between salinities 10 to 60 and temperatures 10 to $30{ }^{\circ} \mathrm{C}$, respectively. This indicated a high degree of euryhalinity and eurythermy for this species, which is common among coastal interstitial animals. Similar results were obtained by Jansen (1970), who observed that the isopod Sphaeroma hookeri was welladapted to survive in a wide range of salinities, but that its survival was reduced at high and low temperatures. The same results were found with the isopod Jaera albifrons (Sjöeberg, 1967). Sphaeroma hookeri, a common species in estuaries, easily tolerated low salinities (Jansen, 1970). For C. ramosae, the survival rate was high in very high salinities, probably because this interstitial isopod lives in the intertidal zone.

C. ramosae tolerated high temperature $\left(30^{\circ} \mathrm{C}\right)$ better than low $\left(5^{\circ} \mathrm{C}\right)$ and also tolerated better salinity variation in high temperatures. This behavior is common among tropical species (Vernberg and Vernberg, 1972; Moreira et al., 1982).

The production of mucus seems to be a response to stressful conditions. Interstitial protozoan secrete mucus, and remain immobile when they are submitted to stressful salinities (Jansson, 1968). All the individuals of $C$. ramosae secreted a mucous layer at the salinity 5 in low temperatures ( 5 and $10^{\circ} \mathrm{C}$ ). This occurred by the abrupt transfer of the individuals to stressful salinities in temperatures very different from that in which they lived in nature. This mechanism reduced the tegument permeability of animal, therefore reducing its water absorption (Kinne, 1964).
The decrease of the organism's activity in stressful salinities was observed by Jansson (1966) in the Mystacocarida Derocheilocaris remanei when submitted to salinity of 60 . C. ramosae showed same behavior at salinity of 70 .

Certain species better tolerate low salinities in low temperatures and high salinities in high temperatures. Other species better tolerate the low/high combination (Kinne, 1971). In the present study, low and high salinities were better tolerated at high temperatures. Tropical animals seem usually to survive better at low salinities in combination with high temperatures (Vernberg and Vernberg, 1970).

Krauss and Found (1975) observed that Derocheilocaris remanei (Mystacocarida) showed the lowest survival at high temperature $\mathrm{x}$ low salinity combination. On the contrary, C. ramosae showed the lowest survival in the combination of low temperature $\mathrm{x}$ low salinity. Present results indicated a tolerance limit between the salinities of 60 and 70 , because at 70 after $3 \mathrm{~h}, 80 \%$ of animals were dead, whereas at 60 at the same temperature, all of them were alive after $24 \mathrm{~h}$.

The statistical analysis indicated that the factor which determined the largest mortality was temperature, probably because the animals were exposed to extreme temperatures $\left(5\right.$ and $\left.35^{\circ} \mathrm{C}\right)$. Hummon (1975) found similar results with interstitial Gastrotricha, where temperature was the main factor for the mortality observed. It is known that the range of ecological temperature of an animal is more restricted than the experimental ones. The best survival conditions for $C$. ramosae were characterized by the combination 15 and $20^{\circ}$ C from 20 to 35 of salinity.

Results showed that the species is well adapted to wide variations of salinity and temperature. $C$. 
ramosae is, therefore, an euryhaline and eurythermic species, and temperature and salinity were not probably responsible for its spatial and temporal distribution on the Praia Vermelha Beach.

These results seemed to confirm the hypothesis of the marine origin of continental of Microcerberids through the interstitial habitat (Coineau and Boutin, 1992), because these physiological characteristics facilitated the entry of these species into the continental underground waters during several geological periods.

\section{ACKNOWLEDGEMENTS}

We thank to $\operatorname{Dr}^{\mathrm{a}}$. Nicole Coineau and Dr. Pierre Noel for their valuable suggestions and the Santa Ursula University and CNPq for financial support.

\section{RESUMO}

A resistência aos efeitos combinados de temperatura e salinidade foi investigada no isópode intersticial Coxicerberus ramosae (Albuquerque, 1978) encontrado comumente na zona intertidal de praias arenosas do Rio de Janeiro, Brasil. Os exemplares foram coletados na Praia Vermelha. Os experimentos tiveram a duração de 24 horas e nove salinidades e sete temperaturas foram utilizadas, perfazendo um total de 63 combinações. Em cada combinação de $\mathrm{T}$ e $\mathrm{S}$ foram testados 30 animais. A espécie mostrou um grande percentual de sobrevivência na maior parte das combinações. A temperatura de $35^{\circ} \mathrm{C}$ foi letal e na temperatura de $5^{\circ} \mathrm{C}$ a espécie resistiu a uma faixa estreita de salinidades. As análises estatísticas mostraram que tanto os efeitos da temperatura como da salinidade e da interação entre estes fatores foram significativos na sobrevivência da espécie. O alto percentual de sobrevivência da espécie nas diferentes combinações de temperatura e salinidade, confirma, portanto, a eurialinidade e a euritermia da espécie, características comuns das espécies intersticiais litorais.

\section{REFERENCES}

Aktas, M., Eroldogan, O. T. and Kumlus, M. (2004), Combined effects of temperature and salinity on egg hatching rate and incubation time of Penaeus semisulcatus (Decapoda Penaidae). Isr. J. Aqua. Bamidgeh, 56 (2), 126-130.

Albuquerque, E. F. (1978), Quatro espécies novas para o Brasil de Microcerberus Karaman, 1933 (IsopodaMicrocerberinae). Rev. Bras. Biol., 38 (1), 201-217.

Albuquerque, E. F. and Genofre, G. C. (1999), Flutuação da população de Microcerberus ramosae (Crustacea: Isopoda) da fauna intersticial da Praia Vermelha, Rio de Janeiro, Brasil. In Silva, S. H. G. and Lavrado, H. P. (eds) Ecologia dos ambientes costeiros do Estado do Rio de Janeiro. Série Oecologia Brasiliensis, vol. VII. PPGE-UFRJ. Rio de Janeiro, Brazil. pp. 229-243.

Avis, A. M. (1988), Temperature and salinity to tolerance of adult hermit crabs, Diogenes brevirostris Stimpson (Crustacea: Decapoda: Anomura). S. Afr. J. Zool., 23 (4), 351-355.

Azis, K. A. and Greenwood, J. G. (1981), A laboratory investigation of temperature and salinity tolerances of juvenile Metapenaeus bennettae Racek and Dall (Crustacea:Penaeidae). J. exp. Mar. Biol. Ecol., 54, 137-147.

Biggs, D. C. and McDermott, J. J. (1973), Variation in temperature-salinity tolerance between two estuarine populations of Pagurus longicarpus Say (Crustacea:Anomura). Biol. Bull., 145, 91-102.

Blaskowski, C and Moreira, G. S. (1986), Combined effects of temperature and salinity on the survival and duration of larval stages of Pagurus criniticornis (Dana) (Crustacea, Paguridae). J. Exp. Mar. Biol. Ecol., 103, 77-86.

Boutin, C. and Coineau, N. (1991), Instabilité des conditions environmentales et vitesse de l'évolution. L'exemple des microcrustacés souterraines d'origine marine dans les pays mediterranéens. Bull. Inst. Géol. Bassin d'Aquitaine, Bordeaux, 50, 63-69.

Cadman, L. R. and Weinstein, M. P. (1988), Effects of temperature and salinity on the growth of laboratoryreared juvenile blue crabs Callinectes sapidus Rathbun. J. Exp. Mar. Biol. Ecol., 121, 193-207.

Christiansen, M. E. and Costlow, J. D. (1975), The effect of salinity and cyclic temperature on larval development of the mudcrab Rhithropanopeus herbstii (Brachiura:Xanthidae) reared in the laboratory. Mar. Biol., 32, 215-221.

Coineau, N. (1971), Les isopodes interstitiels. Documents sur leur écologie et leur biologie. Mem. Mus. Nat. Hist. Nat., Fr., sér. A, 64, 170p.

Coineau, N. (1985), Colonisation du milieu souterrain continental par les organismes d'origine marine moyen d'acces par le milieu interstitiel. Bull. Soc. Biosp., 8, 26-30.

Coineau, N. and Boutin, C. (1992), Biological processes in space and time colonization evolution and speciation in interstitial stygobionts. In: Camacho, A. I. The natural history of biospeleology. 
Monografias, 7, Mus. Nac. Cie, Nat., CSIC, Madrid pp. 423-451.

Dawirs, R. R. (1979), Effects of temperature and salinity on larval development of Pagurus bernhardus ( Decapoda, Paguridae). Mar. Ecol. Prog. Ser., 1, 323-329.

Dorgelo, J. (1976), Salt tolerance in Crustacea and the influence of temperature on it. Biol. Rev., 51, 255-290

Gaudy, R.J.; Guerin, P. E and Moraitou-Apostolopolov, M. (1982), Effect of temperature and salinity on the population dynamics of Tisbe holothuriae Humes (Copepoda:Harpacticoida) fed on two different diets. J. Exp. Mar. Biol. Ecol., 57, 257-271.

Gray, J. S. (1966a), Factors controlling the localizations of populations of Protodrillus symbioticus (Giard). J. Anim. Ecol., 35, 435-442.

Gray, J. S. (1966 b), The attractive factor of intertidal sands to Protodrillus symbioticus. J. Mar. Biol. U. K., 46, 627-645.

Gray, J. S. (1968), An experimental approach to the ecology of the harpacticoid Leptastacus constrictus Lang. J. Exp. Mar. Biol. Ecol., 2, 278-292.

Haefner, P. A. Jr (1969), Temperature and salinity tolerance of the sand shrimp, Crangon septemspinosa Say. Physiol. Zool., 42 (4), 388-397.

Harms, J. (1986), Effects of temperature and salinity on larval development of Elminius modestus (Crustacea, Cirripedia) from Helgoland (North Sea) and New Zealand. Helgoländer wiss. Meeresunters., 40, 355376.

Hummon, W. D. (1975), Respiratory and osmoregulatory physiology of a meiobenthic marine Gastrotrich, Turbanella ocellata Hummon, 1974. Cah. Biol. Mar, 16 (2), 255-268.

Jansen, K. P. (1970), Effect of temperature and salinity on survival and reproduction in Baltic populations of Sphaeroma hookeri Leach, 1814 and S. rugicauda Leach, 1814 (Isopoda). Ophelia, 7, 177-184.

Jansson, B. O. (1962), Salinity resistance and salinity preference of two oligochaetes, Aktedrilus monospermatecus Knölner and Marionina preclitellochaeta n.sp. from the interstitial fauna of marine sandy beaches. Oikos, 13, 293-305.

Jansson, B. O. (1966), On the ecology of Derocheilocaris remanei Delamare and Chappuis (Crustacea, Mystacocarida). Vie Milieu, 17A (1), 143186.

Jansson, B. O. (1967), The importance of tolerance and preference experiments for the interpretation of mesopsammon field distributions. Helgoländer wiss. Meeresunters., 15, 41-58.

Jansson, B. O (1968), Quantitative and experimental studies of the interstitial fauna in four Swedish sandy beaches. Ophelia, 5, 1-71.

Johnson, J. K. (1980), Effects of temperature and salinity on production and hatching of dormant eggs of Acartia californiensis (Copepoda) in an Oregon estuary. Fish. Bull., 77 (3), 567-584.
Jones, M. B. (1972), Effects of salinity on the survival of the Jaera albifrons Leach group of species (Crustacea: Isopoda). J. exp. Mar. Biol. Ecol., 9, 231237.

Kinne, O. (1963), The effects of temperature and salinity on marine and brackish water animals. ITemperature. Oceanogr. Mar. Biol. Ann. Rev., 1, 301-340.

Kinne, O. (1964), The effects of temperature and salinity on marine and brackish water animals. IISalinity and temperature salinity combinations. Oceanogr. Mar. Biol. Ann. Rev., 2, 281-339.

Kinne, O. (1970), Temperature, Animals. Invertebrates. In Kinne O.(ed) Marine Ecology, 1 . WileyInterscience, New York, pp. 407-514

Kinne, O. (1971), Salinity. Animals Invertebrates, In Kinne O. (ed) Marine Ecology, 2, Willey Interscience, New York, pp. 821-995.

Kraus, M. G. and Found, B. W. (1975), Preliminary observations on the salinity and temperature tolerance and salinity preferences of Derocheilocaris typica Pennak and Zinn, 1943. Cah. Biol. Mar., 16, 751-762.

Lemaire, P.; Bernard, E. and Martinez-Paz, J. (2002), Combined effect of temperature and salinity on osmoregulation of juvenile and subadult Penaeus stylirostris. Aquaculture, 209 (1-4), 307-317.

Menet, L.; Alvarez-Osorio, M. T.; GonzalezGuerriarian, E. and Valdés, L. (1991), Effects of temperature and salinity on larval development of Necrore puber (Brachiura: Portunidae). Mar. Biol., 108, 73-81.

Milliou, H. (1977), The effect o temperature, salinity and temperature on juvenile survival, growth and maturation in the polychaete Hydroides elegans. Mar. Ecol. Prog. Ser., 168, 127-134.

Milliou, H. (1996), The effect of temperature, salinity and diet on final size of female Tisbe holothuriae (Copepoda, Harpacticoida). Crustac. Int. J. Crustac. Res., 69(6), 742-754.

Milliou, H. and Moraitou-Apostolopoulou, M. (1991), Combined effects of temperature and salinity on the population dynamics of Tisbe holothuriae Humes (Copepoda: Harpacticoida). Arch. Hydrobiology., 21 (4), 431-448.

Moreira, G. S.; Jillet, J. B.,Vernberg, W. B and Weinrich, M. (1982), The combined effects of Euterpina acutifrons (Dana) (Copepoda, Harpacticoidea) from the New Zealand and Brazilian Coasts. J. Plankton Res., 4 (1), 85-91.

Moreira, G. S.; McNamara, J. C. and Moreira, P. S. (1986), The effect of salinity on the upper thermal limits of survival and metamorphosis during larval development in Macrobrachium amazonicum (Heller) (Decapoda, Palaemonidae). Crustac. Int J. Crustac. Res, 50 (3), 231-238.

Ong, K.-S. and Costlow, J. D. Jr. (1970), The effect of salinity and temperature on the larval development of 
the stone crab, Menippe mercenaria (Say), reared in laboratory. Cheseap. Sci.11(1), 126-29.

Paula, J.; Nogueira Mendes, R.; Mwalum, J.; Raedig, C. and Emmerson, W. (2003), Combined effects of temperature and salinity on larval development of the mangrove crab Parasesarma catenata Ortman, 1897 (Brachyura: Sesarmidae)of Western Indian Ocean. $J$. Mar. Sci, 2(1), 57-63.

Preston, N. (1985), The combined effects of temperature ad salinity on hatching success and the survival, growth, and development of the larval stages of Metapenaeus brunnettae (Racek and Dall). J. Exp. Mar. Biol. Ecol. 87, 229-240.

Qiu, J. W. and Qian, P. Y. (1997), Combined effects of salinity, temperature and food on early development of the polychaete Hydroides elegans. Mar. Ecol. Prog. Ser., 152, 77-88.

Qiu, J. W. and Qian, P. Y. (1998), Combined effects of salinity and temperature on juvenile survival, growth and maturation in the polychaete Hydroides elegans. Mar. Ecol. Prog. Ser., 168, 127-134.

Roddy, B. D.; Leakey, R. J. G. and Berry, A. J (1984), Salinity-temperature tolerance and osmoregulation in Eurytemora affins (Poppe) (Copepoda: Calanoida) in relation to its distribution in the zooplankton of the upper reaches of the Forth estuary. J. Exp. Mar. Biol. Ecol., 79, 191-211.

Rosenberg, R. and Costlow, J. D. (1976), Synergistic effects of cadmium and salinity combined with constant and cycling temperatures on the larval development of two estuarine crab species. Mar. Biol., 38, 291-303.

Rothlisberg, P. C. (1979), Combined effects of temperature and salinity on the survival and growth of the larvae of Pandalus jordani. Mar. Biol., 55, 125-134.

Salvat, B. (1964), Les conditions hydrodinamiques interstitielles des sédiments meubles intertidaux et la répartition verticale de la faune endogée. CR. Acad. Sci. Paris, 259, 1576-1579.

Sandifer, P. A. (1973), Effect of temperature and salinity on larval development of glass shrimp Palaemonetes vulgaris (Decapoda, Caridea). Fish. Bull. NOAA, 71, 115-123.

Segal, E. and Burbancki, W. D. (1963), Effects of salinity and temperature on osmoregulation in two latitudinally separated populations of an estuarine isopod, Cyathura polita (Stimpson). Physiol. Zool., 36, 250-263.

Sjöeberg, B. (1967), On the ecology of the Jaera albifrons group (Isopoda). Sarsia, 29, 321-348.

Thiyagarajan, U., Harder, T. and Qian, P. U. (2003), Combined effect of temperature and salinity on larval development and attachment of the survival barnacle Balanus trigonus Darwin. J. Exp. Mar. Biol. Ecol., 287, 223-236.

Todd, M.-E. and Dehnel, P. A. (1960), Effect of temperature and salinity on heat tolerance in two grapsoid crabs, Hemigrapsus nudus and Hemigrapsus oregonensis. Biol. Bull., 118, 150-172.

Vernberg, F. J. and Vernberg, W. B. (1970), The animal and the environment. Holt Rinehart and Winston, New York.

Vernberg, W. B. and Coull, B. C. (1975), Multiple factors effects of environmental parameters on the physiology ecology and distribution of some marine meiofauna. Cah. Biol. Mar., 16 (5), 721-732.

Vernberg, W. B. and Coull, B. C. (1981), Meiofauna. In: Vernberg, F. J. and Vernberg, W. B., (eds). Functional adaptations of marine organisms. N.Y., Academic Press, pp. 147-177.

Vernberg, W. B. and Vernberg, F. J. (1972), Environmental Physiology of Marine Animals. New York, Springer-Verlag.

Vinuesa, J. H.; Ferrari, I. and Lombardo, R. J. (1985), Effect of temperature and salinity on larval development of southern king crab (Lithodes antarcticus). Mar. Biol., 85, 83-87.

Vlasbom, A. G.; Graafsma, S. J. and Verhoeven, J. T. A., 1977, Survival, osmoregulatory ability, and respiration of Idotea chelipes (Crustacea, Isopoda) from Lake Veere in different salinities and temperatures. Hydrobiologia, 52(1), 33-38.

Wägele, J. W.; Voelz, N. J. and McArthur, J. V. (1995), Older than the Atlantic Ocean: discovery of a freshwater Microcerberus (Isopoda) in North America and erection of Coxicerberus, new genus. J. Crust. Biol., 15(4), 733-745.

Wieser, W. and Shiemer, F. (1977), The ecophysiology of some marine nematodes from Bermuda: seasonal aspects. J. Exp. Mar. Biol. Ecol., 26, 97-106.

Yagi, H. and Ceccaldi, H. J. (1983), Croissance, survie et respiration des stades larvaires de Palaemon serratus (Prennant), Crustacea Decapoda, a différentes combinaisons de salinité et de température. Rapp. Comm. int. Mer. Médit., 28 (6), 345-348.

Young, A.M. (1991), Temperature-salinity tolerance of two latitudinally separated populations of the long wrist hermit crab Pagurus longicarpus Say (Crustacea, Decapoda, Paguridae). Ophelia, 34 (1), 29-39.

Young, A. M. and Hazlett, T. L. (1978), The effect of salinity and temperature on the larval development of Clibanarius vittatus (Bosc) (Crustacea: Decapoda: Diogenidae). J. Exp. Mar. Biol. Ecol., 34, 131-142.

Zar, J. H. (1999). Biostatistical analysis. $4^{\text {nd }}$. ed. Englewood Cliffs, N.J., Prentice-Hall.

Received: May 17, 2006; Revised: March 23, 2007; Accepted: March18, 2009. 